\title{
Report on the ICDP workshop DIVE (Drilling the Ivrea-Verbano zonE)
}

\author{
Mattia Pistone $^{1}$, Othmar Müntener ${ }^{1}$, Luca Ziberna ${ }^{2}$, György Hetényi ${ }^{1}$, and Alberto Zanetti ${ }^{3}$ \\ ${ }^{1}$ Institute of Earth Sciences, University of Lausanne (UNIL), Bâtement Géopolis, Quartier UNIL-Mouline, \\ 1015, Lausanne, Switzerland \\ ${ }^{2}$ Bayerisches Geoinstitut, University of Bayreuth, 95440 Bayreuth, Germany \\ ${ }^{3}$ Istituto di Geoscienze e Georisorse, Consiglio Nazionale delle Ricerche (CNR), Pavia, \\ Via Ferrata, 1, 27100 Pavia, Italy \\ Correspondence to: Mattia Pistone (mattia.pistone@unil.ch)
}

Received: 7 July 2017 - Revised: 16 October 2017 - Accepted: 17 October 2017 - Published: 30 November 2017

\begin{abstract}
The Ivrea-Verbano Zone is the most complete, time-integrated crust-upper mantle archive in the world. It is a unique target for assembling data on the deep crust and the Moho transition zone and testing several hypotheses of formation, evolution, and modification of the continental crust through space and time across the Earth. The ICDP workshop Drilling the Ivrea-Verbano zonE (DIVE), held in Baveno, Italy, from 1 to 5 May 2017, focused on the scientific objectives and the technical aspects of drilling and sampling in the IvreaVerbano Zone at depth. A total of 47 participants from 9 countries with a wide variety of scientific and/or drilling expertise attended the meeting. Discussion on the proposed targets sharpened the main research lines and led to working groups and the necessary technical details to compile the full drilling proposal. The participants of the workshop concluded that four drilling operations in the Val Sesia and Val d'Ossola crustal sections represent the scientifically most promising solution to achieve the major goals within DIVE to unravel the physico-chemical properties and architecture of the lower continental crust towards the crust-mantle (Moho) transition zone.
\end{abstract}

\section{Introduction}

The Drilling the Ivrea-Verbano zonE (DIVE) project aims at unravelling the chemistry, physics, and microbiology of the roots of the Earth's continental crust and the crust-mantle transition or Moho transition zone in the most complete, time-integrated crust-upper mantle archive in the world: the Ivrea-Verbano Zone (IVZ). The IVZ and the adjacent "Serie dei Laghi" (Boriani et al., 1990) expose a crustal section of the southern Alpine basement and is a southwest-northeast elongated body in the western Alps of Italy and Switzerland (Fig. 1). This body was the first region interpreted as an exposed cross section of the entire continental crust (e.g. Berckhemer, 1968; Fountain, 1976), with the lowermost part representing the laminated lower crust, known from seismic sections all over the world and characterised by multiple densely packed sets of reflectors referred to as seismic lamellae (e.g. Fountain, 1976; Rutter et al., 1993; Weiss et al., 1999).
A team of 47 scientists gathered for a workshop held in Baveno, Italy, to discuss scientific aims, drilling sites, and the technical and societal aspects of the DIVE project. Expertise of the participants ranges from petrology, geochemistry, geophysics, field geology, microbiology, scientific drilling, and drilling engineering. A series of introductory talks, plenary discussions, and working group meetings allowed ideas to be assembled and sharpened that will be used for the full drilling proposal.

A major issue that has sparked worldwide interest is the Ivrea geophysical body, a large gravimetric, magnetic, and seismic anomaly indicating that dense, mantle-like rocks are located at fairly shallow crustal levels (locally $\sim 3 \mathrm{~km}$ depth; Berckhemer, 1968; Lanza, 1982; Kissling, 1984; Wagner et al., 1984; Diehl et al., 2009; Figs. 2-3). The Ivrea geophysical body, in its northern part, has a surface exposure, known as the Ivrea-Verbano Zone. Although some of the results on this zone are uncertain and the subject of continuing debate, 


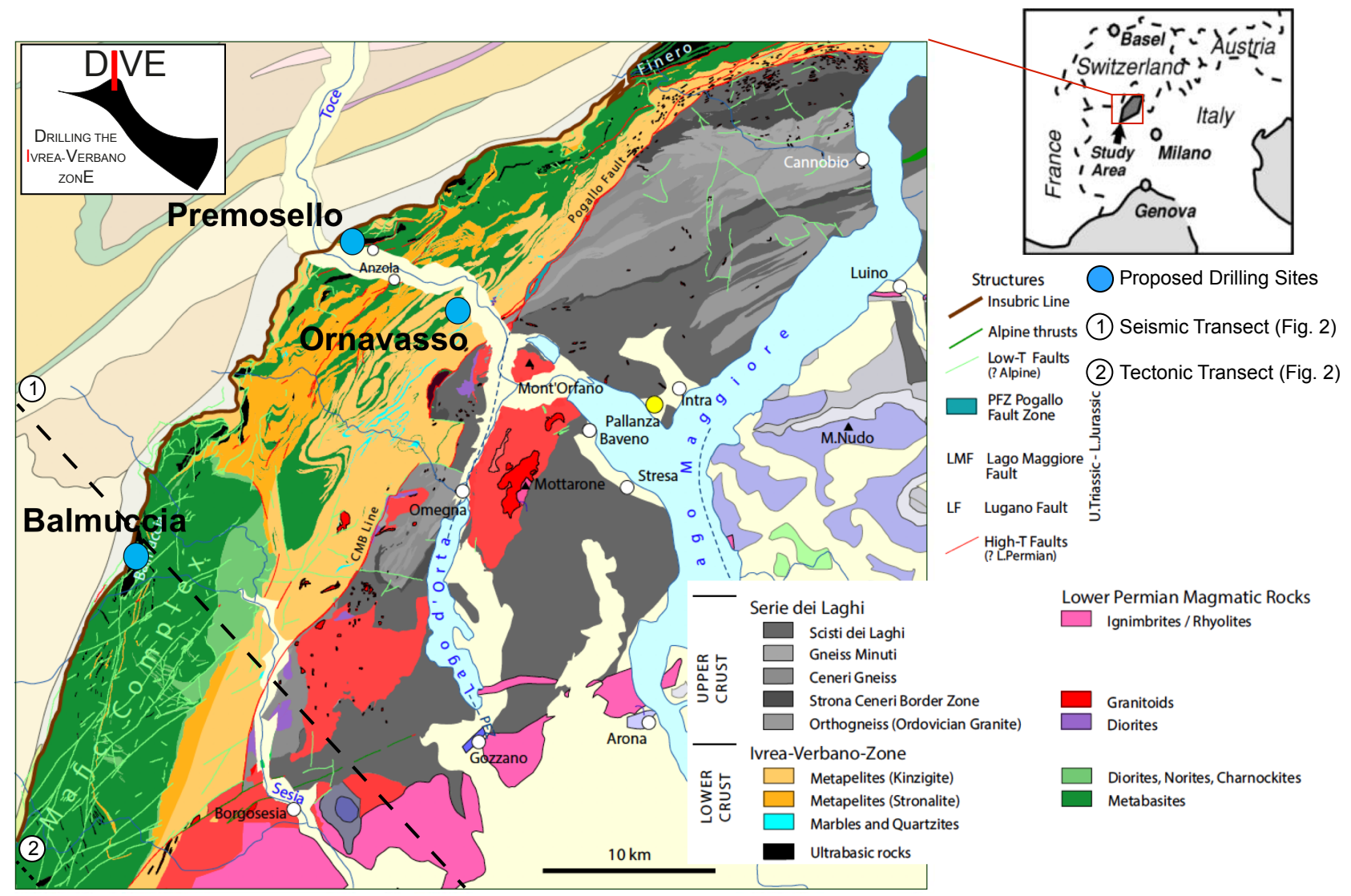

Figure 1. Overview of the geology of the IVZ and adjacent units, simplified after a compilation of James (2001) and Brack et al. (2010). The blue circles indicate the discussed drilling sites for the DIVE project. The inset figure showing the location of the IVZ in Italy is from Rutter et al. (2003).

it was clearly pointed out by the participants that work in the IVZ has played and still plays a fundamental role in shaping the debate on the origin of the lower continental crust and its transition into the mantle. Indeed, it makes an interesting case since the exposed Ivrea continental crustal section is made by two quite different sections both in composition and time. Hypotheses based on the Ivrea lower crust and crustmantle transition zone have clearly delineated the need for additional data to resolve some fundamental yet complementary questions. This report presents the results of the workshop.

\section{DIVE manifesto: project goals of the ICDP in the Ivrea-Verbano zone}

The goals of the planned research are summarised below:

i. identifying the major characteristics of the deep structure and composition of the continental crust-mantle transition zone (this requires complete characterisation of the rock properties such as mineral and bulk compo- sition, alteration, shear zones and faults, the relation of permeability to alteration, and fluid characterisation)

ii. systematic compositional study of complete sections of the lower continental crust and the crust-mantle transition zone, with emphasis on crucial transitions between peridotite and metasedimentary and gabbroic rock interfaces

iii. characterisation of physical properties of the drilled sections to refine techniques used in studies of the continental crust to improve the identification and nature of seismic reflectors (this is fundamental for upand down-scaling observations from the kilometre-scale geophysics to centimetre-scale observations on core samples)

iv. study of fluid-rock interaction in pristine rocks, and fluid flow and permeability along major tectonic structures such as shear zones and faults (this investigation also allows the study of the beginnings of serpentinization processes in nearly pristine mantle peridotite) 


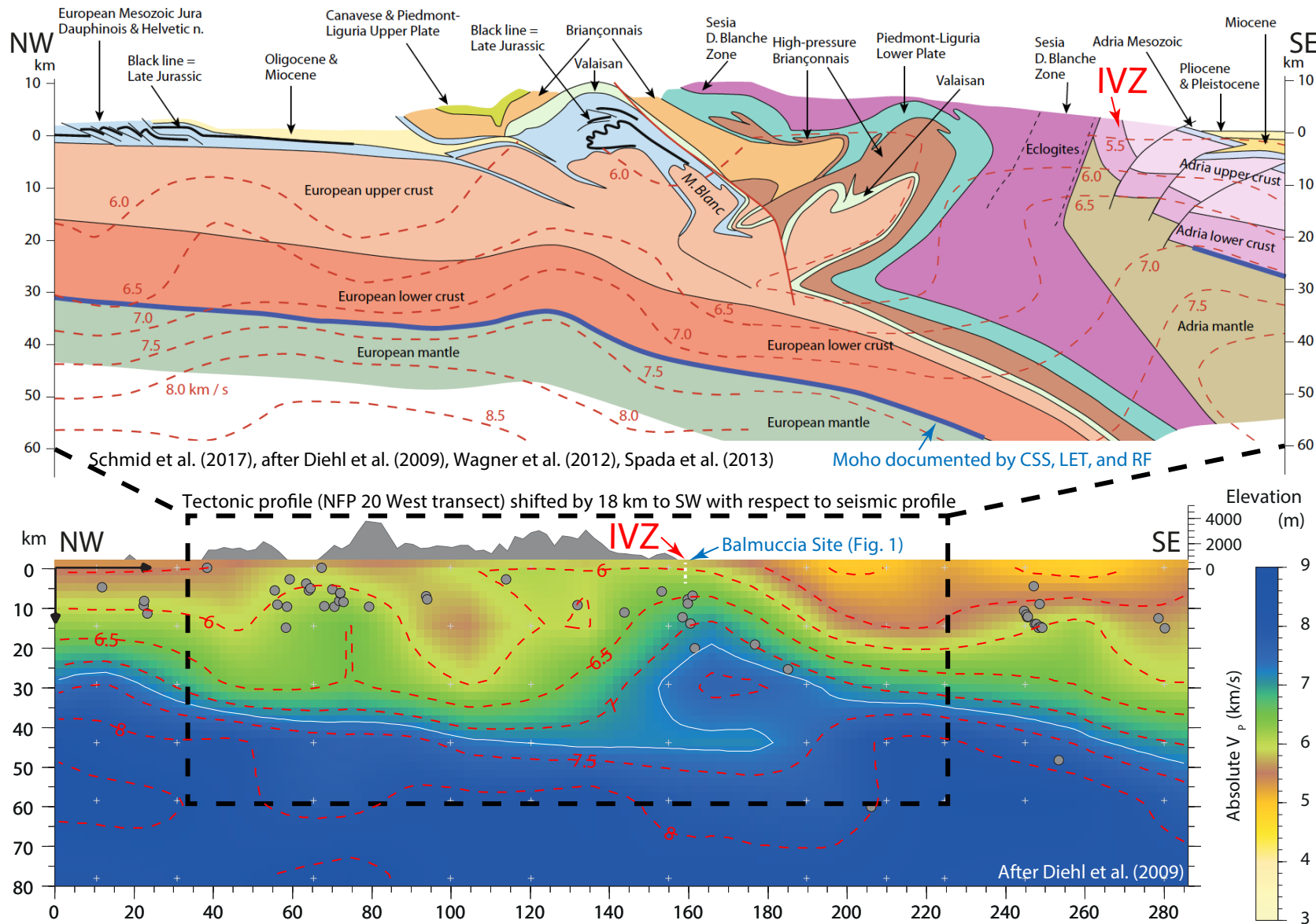

Figure 2. Northwest-southeast geological-tectonic transect (NFP 20 western transect; Schmid et al., 2017) and seismic profile (Diehl et al., 2009) across the western Alps. The two profiles are superimposed with and partly based on vertical cross sections across the final P-wave velocity model of Diehl et al. (2009), indicated by red dashed lines. The Moho (blue line in the geological-tectonic profile) is taken from a combination of controlled-source seismology (CSS), local earthquake tomography (LET), and receiver function (RF) analysis (Wagner et al., 2012; Spada et al., 2013). Data sources and traces of the profiles are reported in Schmid et al. (2017). The vertical white dashed line in the seismic profile indicates the proposed core location (up to $4 \mathrm{~km}$ depth) of Balmuccia site (Fig. 1). Note that the tectonic profile (NFP 20 western transect) is shifted by $18 \mathrm{~km}$ to the southwest with respect to the seismic profile.

v. unravelling the extreme niches for hosting microbial life in planetary interiors, the fluid flow conditions that sustain life, as well as the hydrosphere and atmosphere on Earth, and the geochemical contexts of organic compound synthesis at depth

vi. detailed and direct downhole geophysical monitoring of natural and human-induced seismicity, evaluation of seismic hazards near the major suture zone of the Alpine orogeny, and new insights on geothermal energy exploration

vii. The development of a permanent educational, touristic, and research centre in the IVZ ("The ear into the Earth").
To achieve these goals, drilling operations at three key sites in the area of the IVZ (Fig. 1) have been discussed and prioritised.

- Balmuccia, Val Sesia (peridotite sliver and gabbros of the lower crust in proximity of the Insubric Line, the structure depicted with a brown line in Fig. 1): deep drilling into the roots of a large-scale Permian magmatic system from the lower crust to the surface, with the main goal to approach the crust-mantle transition zone and benchmark it against geophysical data

- Premosello, Val d'Ossola (peridotite sliver, hightemperature shear zones): drilling into the pre-Permian continental lower crust with high lithological variability, in the fold hinges of large-scale folds to investigate peridotite-gabbro-metasedimentary interfaces 

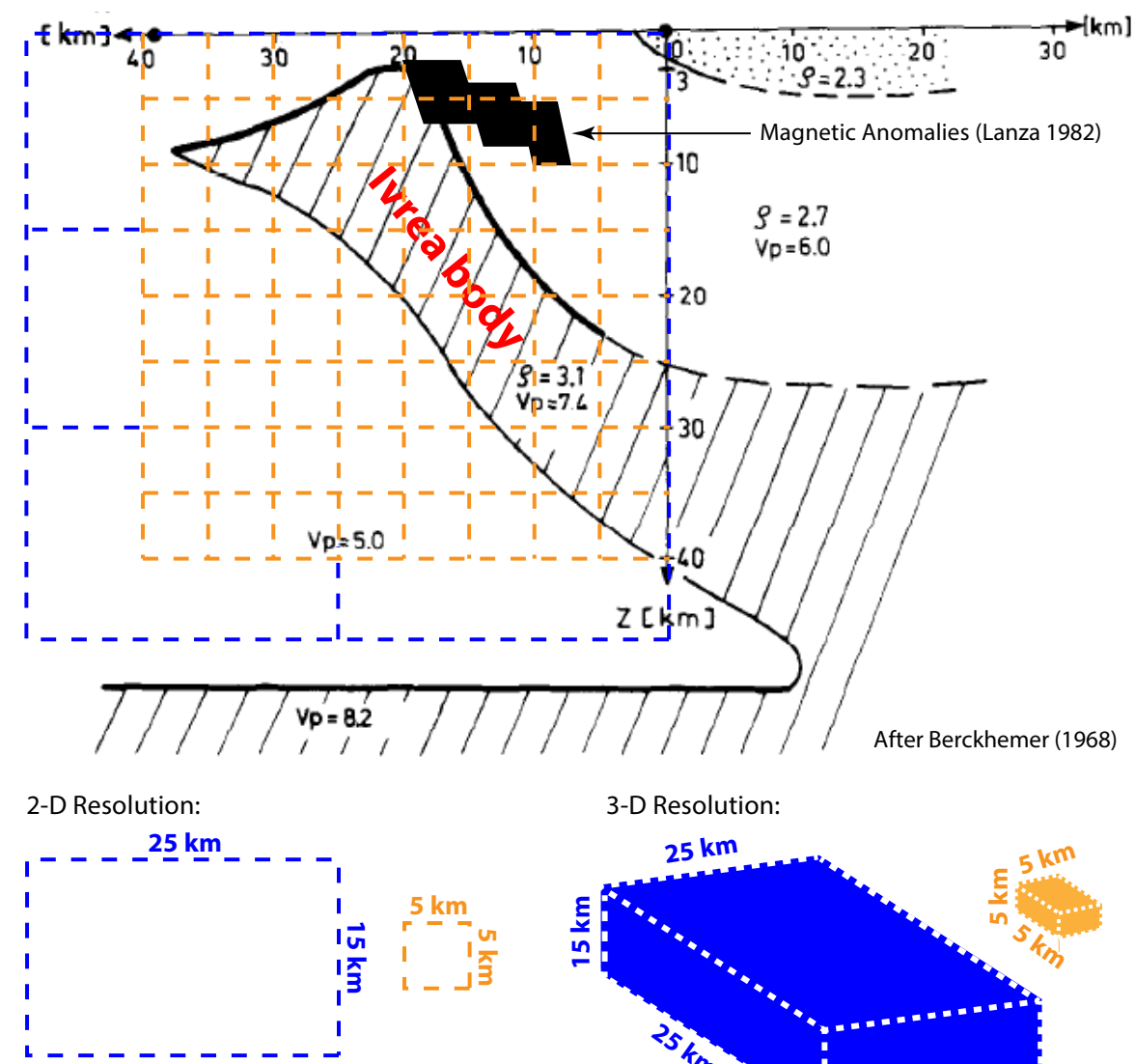

3-D Resolution:
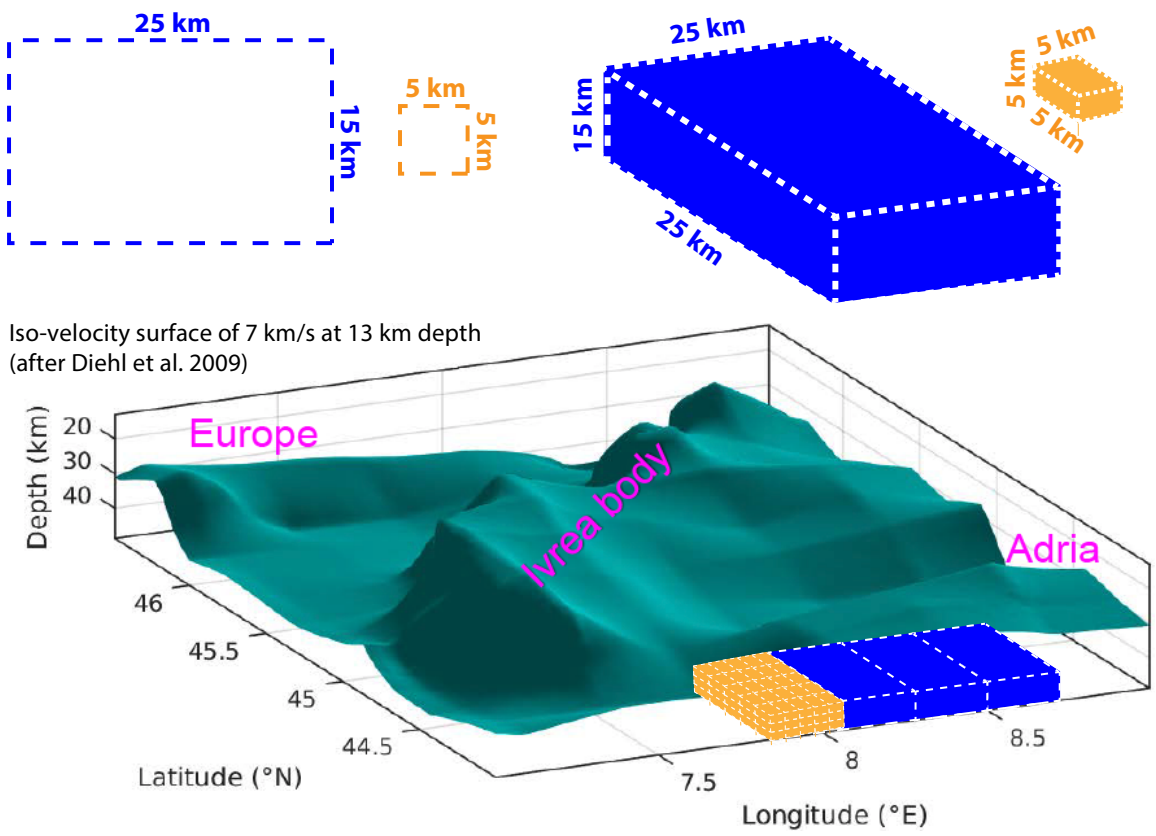

Figure 3. Cross section of the Ivrea body ("Bird's Head model") according to Berckhemer (1968), as determined by seismic wave velocities and gravity anomalies. Black squares are magnetically differentiated rocks with a magnetic susceptibility contrast of $5 \times 10^{-1}$ CGS EMU (electromagnetic units in the centimetre-gram-second system) with respect to the surrounding lithologies (Lanza, 1982). Blue dashed grid indicates 2-D spatial seismic resolution achieved in the past $(25 \mathrm{~km} \times 25 \mathrm{~km}$ [horizontal] $\times 15 \mathrm{~km}$ [vertical]; Diehl et al., 2009). Orange dashed grid indicates 2-D spatial seismic resolution $(5 \mathrm{~km} \times 5 \mathrm{~km} \times 5 \mathrm{~km})$ to be applied in the forthcoming geophysical investigations. The higher spatial seismic resolution will allow improvements of existing 3-D geophysical models (e.g. iso-velocity surface models of Diehl et al., 2009) to image the Ivrea body at depth.

- Ornavasso, Val d'Ossola (amphibolite-facies, metasedimentary sequence in the Massone antiform): drilling into the pre-Permian heterogeneity of the intermediate to lower crust in the fold hinges of metasedimentary sequences.
In an initial phase (Phase I), each of the proposed drilling operations is planned to generate $\sim 1 \mathrm{~km}$ of continuous coring of rocks and to sample representative sections of the Ivrea continental lower crust. A fourth drilling operation (Phase II) aimed at coring deeper into the crust-mantle transition zone 
(up to $4 \mathrm{~km}$ ) is planned as part of the second stage of drilling. The preferred site for deep drilling is the Balmuccia site but might be modified according to the results of the Phase I of drilling.

Each of these proposed sites are carefully studied by predrilling investigations, which include target-oriented geological site surveys aimed at determining the main structural architecture, pressure gradients in space and time across metamorphic sections, fluid and heat budgets of the crust, petrophysical properties of the lower crust, and several-kilometredeep geophysical characterisation of the IVZ structure.

The participants of the workshop agreed that drilling is essential because drilled cores provide complete sections of the continental crust-mantle transition zone that can be compared to existing data. The outcrops of the IVZ have been investigated by the worldwide scientific community in the last 50 years, and for many models on the lower continental crust the IVZ is a reference case (e.g. Salisbury and Fountain, 1990). Specifically, the overall picture and the deep threedimensional structure are sufficiently well known to document beyond any doubt that, in the IVZ, at shallow depth, and possibly even at the surface, representative sections of the continental lowermost crust of the Adria plate are exposed (Figs. 2-3). This, combined with continuous drilling in key sites of the IVZ, would allow unravelling the complexity of a complete lower crustal section and contributing substantially to refining hypotheses on the genesis and dynamics of the Earth's continental lower crust and Moho transition zone, on continental extension, and on the deep structure of crustal-scale magmatic plumbing systems. Continuous sampling across a number of kilometre-long drilling sections will provide access to hitherto the inaccessible, deepest portions of the continental crust, which are not exposed in the IVZ. This will in turn provide the opportunity to unravel the architecture and chemistry of the composite Moho transition zone, and, therefore, calibrate current tectonic, geophysical, and petrological models.

This ICDP workshop addressed the aspects and challenges of drilling targets, in situ well loggings, core analysis, and scientific collaborations and partnerships as well as operations, logistics, funding, permissions, outreach, education, and cooperation with national, regional, and municipal authorities. It was envisioned that drilling will be funded by the ICDP, industry, national and international science funding agencies such as the European Research Council (ERC), Swiss National Science Foundation (SNF), Italian Research Council (Consiglio Nazionale delle Ricerche or CNR), National Institute of Volcanology and Geophysics (Istituto Nazionale di Vulcanologia e Geofisica or INGV), German Research Foundation (Deutsche Forschungsgemeinschaft or DFG), Deep Carbon Observatory (DCO) Task Force 2020, US National Science Foundation (NSF), US National Aeronautics and Space Administration (NASA), European Space Agency (ESA), and Italian Space Agency (Agen- zia Spaziale Italiana or ASI). The DIVE research plan is subdivided into five main themes as follows.

\section{Petrology, geochemistry, and structural geology}

The IVZ is a unique target for assembling direct data on the deep crust and the crust-mantle transition zone and testing several hypotheses of generation, construction, and evolution of the continental crust through space and time across the Earth. Drilling in Balmuccia should ultimately provide a deep borehole up to $4 \mathrm{~km}$ depth to approach the crust-mantle transition determined by geophysical imaging (e.g. Diehl et al., 2009; Fig. 2), or even reach it. Drilling in Premosello and Ornavasso (Fig. 1) will be planned in order to systematically cross interfaces, such as the intercalations of amphibolite to granulite facies metasedimentary and metavolcanic rocks, the transition into denser rock types (pyroxenites and/or restitic garnet-rich gneisses), and eventually the peridotitic rock types to characterise the continental Moho transition zone. Planning will be constrained by compiled site survey based on detailed geological investigations.

Petrologists and geochemists of the ICDP workshop proposed the following research themes to explore by deep drilling investigations.

1. The first theme is correlation of crustal lithostratigraphy and seismic structures with new integrated petrological and geophysical models. In continental areas the interpretation of seismic, density, and magnetic structures have largely been based on correlations with exposed lower crustal rocks. Similarly, the continental seismic Moho has been interpreted as a transition from lower crustal to mantle rocks. The IVZ provides sections of the lower continental crust with different compositions (mafic versus metasedimentary) where inter-fingering of mantle and crustal rocks are observed and, therefore, it is unclear where the seismic transition to the mantle might be found and how lateral differences in lower crustal compositions can seismically be detected (Fig. 4). Downhole variations in rock types, physical properties and alteration degree might help to better calibrate seismic models.

2. The second theme is the evaluation of budgets of carbon and heat-producing elements ( $\mathrm{U}, \mathrm{Th}$, and $\mathrm{K}$ ) of the metapelitic crust, to establish (a) similarities and differences between amphibolite facies (Kinzigite) and granulite facies (Stronalite) rocks in statistical samples along cores, and (b) mass balance of heat-producing elements from compositional and logging data, whose distributions vary within the Kinzigite formation, granulites, and the contact aureole around the Mafic Complex. The deep carbon cycle, the heat budget, and the IVZ crustal dynamics in the pre-Permian, as well as Permian period (i.e. before and after the emplacement of the Mafic 
Complex and generation of granitic systems in the upper crust and volcanoes at the surface), will help reconstruct the influence of geochemistry on the potential ecology of extreme environments and determining the prohibitive and unrestrictive conditions for microbial life in the Earth's interior (e.g. Morrison et al., 2017).

3. The third theme is the identification and size-frequency distribution of shear zones and fractures to distinguish low temperature features related to exhumation from high temperature structures during accretion and/or crustal thinning.

4. The fourth theme is deformation-assisted fluid extraction processes and fluid percolation during emplacement and cooling of the lower crust.

5. The fifth theme is the quantification of chemical and physical differences and similarities between mafic and metasedimentary lower continental crust.

6. The sixth and final theme is the testing of emplacement models of deep crustal intrusions (e.g. "gabbro glacier" model; Sleep, 1975; Quick et al., 1994) or sills (e.g. "sill emplacement" model; Annen and Sparks, 2002; Solano et al., 2014). Observations along drilling transects by determining the compositional and textural variability of the gabbros in the lower crust and linking them to downhole geophysical logs will provide crucial data that will aid understanding of the mechanism of emplacement of lower crustal mafic bodies across the Earth.

\section{Geophysics}

During the ICDP workshop, geophysicists of different disciplines addressed the following research targets to be investigated during pre-drilling surveys, drilling operations, and complementary field experiments:

1. The geometry of mantle-derived ultramafic bodies and their transition or connection to lower crustal rocks (i.e. high-resolution refinement of the "Bird's Head model" reported in Berckhemer, 1968; Fig. 3);

2. Quantitative assessment of the nature and scale of mineralogical variations and fabrics along a finely banded sequence;

3. The size-frequency distribution of fractures and veins and relationships to the geometry of Alpine thrusts and pre-Alpine faults, including the subsurface continuation of the Insubric Line;

4. The hydration evolution of crustal rocks with depth.

The larger-scale research objectives will be tackled in combination with the ongoing European AlpArray project (Hetényi, 2012; Hetényi and AlpArray Working Group, 2012a, b;
Molinari et al., 2016; www.alparray.ethz.ch), and a targeted, 10 -station broadband seismological array operated from June 2017 (Scarponi et al., 2017).

In terms of crustal structure, the currently highest and most uniform resolution seismological image and interpretation of the IVZ is provided by Diehl et al. (2009) and subsequent works (Fig. 2). Their investigation is carried out using a $25 \times 25$ (horizontal) $\times 15$ (vertical) $\mathrm{km}$ grid (Fig. 3). If a finer-scale local earthquake P- and S-wave tomography is attempted, a dense local network with a minimum of 2 to 3 years of operation and inversion on a $5 \times 5 \times 5 \mathrm{~km}$ grid is required (Fig. 3). In addition, this will be completed by existing surface tectonic studies of the IVZ (Fig. 2).

High-resolution geophysical investigation is of primary importance to approach the scale of geological knowledge; nevertheless, cross-scale connection of physical properties is not necessarily granted (see Fig. 4 for a comparison of various exposed lithologies and similar seismic wave velocities). Therefore, a multidisciplinary combination of shallow and deep geophysical investigations was proposed, ranging from active seismics (especially pre-site surveys in the Balmuccia site), passive seismology (a 10-station broadband array to investigate the Bird's Head with receiver functions (Scarponi et al., 2017), magnetotellurics, and gravity anomalies (to map the three-dimensional buried morphology of the Ivrea geophysical body; Fig. 3) in the period 2017-2020. Drilling into the geophysically imaged volume can provide an additional approach: any fracturing process, likely enhanced by fluid circulation in and around the borehole, will be the induced source of micro-earthquakes, which is aimed at being recorded with a dedicated, targeted seismic network. In addition, once the borehole is considered complete, vertical seismic profiling (i.e. a technique devoid of blasting, employed in the recent ICDP-COSC project in Sweden; Lorenz et al., 2015) will provide an outstanding controlled-source complement to the dataset.

\section{Well logging and rock physics}

An international consortium of scientists will analyse the cores and conduct downhole geophysical experiments to investigate permeability, state of stress, and fracture distribution, as well as the magnetic, seismic, and resistivity properties of the lithological types in the continental lower crust and Moho transition zone.

Comprehensive downhole logging will provide a continuous, in situ, highly resolved record of key physical, chemical, and structural rock information along the entire length of the drilled lithological sequences. This, in turn, will allow for the linking of micro- to centimetre-scale observations from drill core samples to field-scale geophysical observations of the continental crust in general and in particular the IVZ. Downhole logging permits the compensation, in part, for the inevitably incomplete retrieval of 


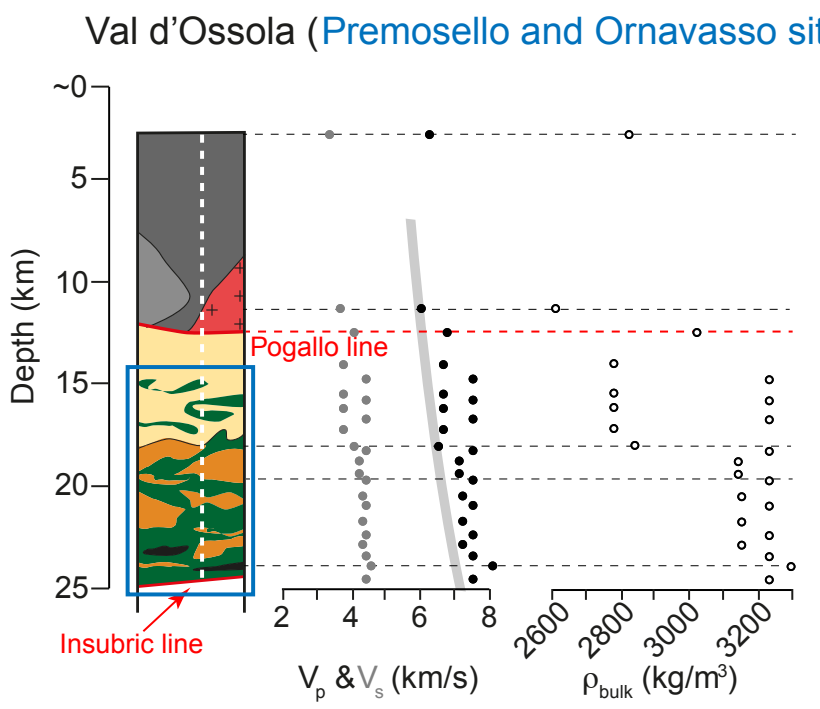

Upper crust

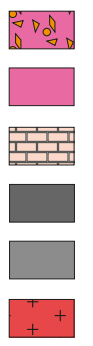

Caldera fill

Volcanic rocks

Limestones

Schists

Gneisses

Granitic rocks
Lower crust

Metapelite (Kinzigite)

Metapelite (Stronalite)

Charnockitic rocks

Diorite

Gabbronorite

Amphibole-gabbro
Val Sesia (Balmuccia site)

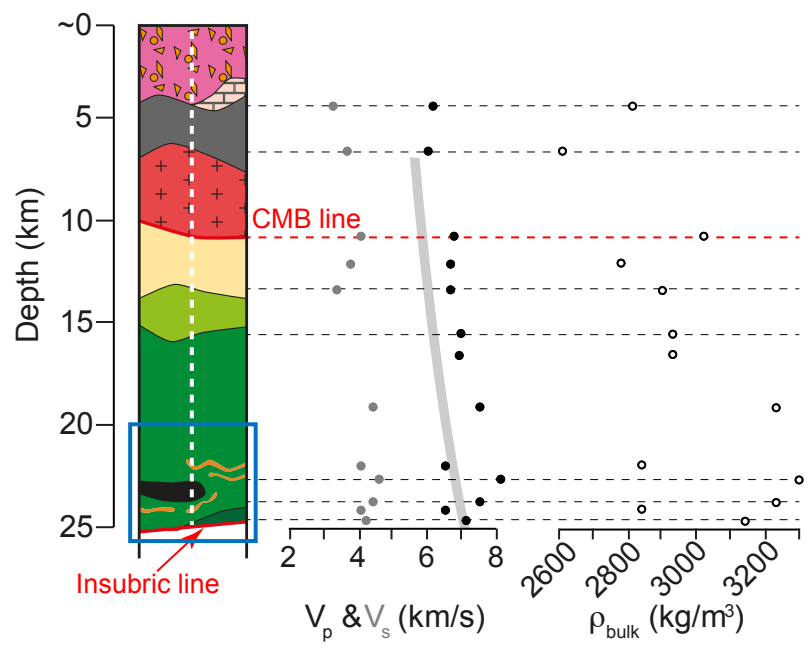

Lower crust-upper mantle

Ultramafic rocks

Laboratory measurements (Khazanehdari et al. 2000)

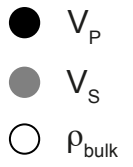

Figure 4. Schematic lithological, seismic, and density properties of bulk rocks from the main geological locations of the IVZ where the ICDP DIVE project will be targeted. Lithological data are from James (2001), Quick et al. (2003), Sinigoi et al. (2011), and Klötzli et al. (2014). Average bulk rock seismic P-wave and S-wave velocity $\left(V_{\mathrm{P}}\right.$ and $\left.V_{\mathrm{S}}\right)$ and density $\left(\rho_{\text {bulk }}\right)$ data are from Khazanehdari et al. (2000). The white dashed line indicates the pathway of plotted bulk rock seismic velocity and density data for each different lithology along the cross section. Grey band shows global average $V_{\mathrm{P}}$-depth relation for extended terrains (Christensen and Mooney, 1995). Blue squares highlight the lithologies at the drilling sites displayed in Fig. 1.

core material, although hard-rock drilling is often characterised by excellent coverage (up to $100 \%$ ). Important rock physical properties to be measured by downhole logging are $\mathrm{P}$ - and S-wave velocities in the sonic frequency range and the electrical conductivity. The sonic measurements will be complemented by P-wave vertical-seismic-profile (VSP)type surface-to-borehole measurements in the higher seismic frequency range. Together, these observations can then be correlated with results from corresponding crustal-scale geophysical investigations as well as petrophysical laboratory measurements on the retrieved core material.

Additional pertinent rock physical properties provided by downhole logging will be natural radioactivity, density and porosity, possibly in conjunction with neutron-neutron logging. Panoramic $\left(360^{\circ}\right)$ televiewer logging will generate high-resolution images of the structural fabric along the borehole. This does not only offer a highly resolved continuous record of key structural parameters along the entire borehole, such as the strike and dip of the fractures, fabrics, and lithological interfaces, but also enables the construction of digital pseudo-cores, which can then be visually correlated with the retrieved core material. Combined with the standard caliper logs, such televiewer images will further permit the detection and orientation of breakouts, which, in turn, will critically constrain the nature and orientation of the prevailing presentday stress field. Petrographic studies on cores will be used to learn how geophysical logs record information about igneous rocks and interlayered metasedimentary rocks or septa in the lower continental crust and the crust-mantle transition zone, yielding a continuous record of layer spacing from the geophysical logs even where core is not recovered. This can be combined with geophysical data to identify septa-related reflectors. Finally, flow-meter logging and downhole fluid sampling and temperature measurements will provide constraints with regard to fluid flow and permeability, as well as the com- 
position and origin of the fluids prevailing the pores and fractures of the probed lithologies.

Advanced packer systems could be used during the drilling process to assess possible fluid or gas discharge from permeable layers to analyse the relation between prevailing hydraulics and fluid composition with the petrology and the texture of the fluid-bearing rocks. In particular, noble gases and other transient tracers (e.g. ${ }^{3} \mathrm{H}$ and ${ }^{14} \mathrm{C}$ ) will be analysed to trace the geochemical origin of the fluids (i.e. mantlederived vs. crustal) and determine the water residence time. The lesson from scientific drilling in the context of nuclear waste disposal and geothermal exploration is that such fluid analyses during the drilling process are essential to analyse rock-water interactions. During the discussion, consideration was also given to keeping the boreholes open, allowing later fluid and water sampling under natural conditions after re-equilibration of drilling process disturbances.

\section{Geohazards and long-term monitoring}

The DIVE project will provide the opportunity to implement long-term seismic monitoring after coring ( $>10$ years), and possibilities for additional monitoring are being investigated (e.g. downhole temperatures, new heat flow data, dynamics of freshwater, downhole pressures, Earth magnetism, in situ microbiological tests at high pressure). Scientifically longterm seismic monitoring is necessary for an in-depth understanding of microfractures, fault reactivation, and rupturing. Data retrieved from greater depths are needed for validating existing geophysical, petrological, and geomechanical models. In situ and laboratory biological data are also an essential aspect of the drilling project, which can potentially reveal the extent and limits of the deep biosphere in the continental lower crust. Very limited data from boreholes in marine and terrestrial environments have been collected so far. The greater depth and temperature limits of the biosphere have not been reached in any borehole studies that have included a microbiological component, and the factors controlling the abundance and activities of microbes at depth and the lower depth limit of life are still poorly understood. Last but not least, the DIVE project should trigger a large-scale international network of collaborations and partnerships that could lead to the generation of a research and teaching centre of excellence in the IVZ in the long term. Specifically, it is of great importance to establish a novel international observatory in which scientists of different expertise from all over the world can visit the IVZ and integrate fieldwork, modelling, experiments, and theories to advance knowledge and technology in our society.

\section{Societal impact and relevance of the IVZ}

The research themes of the proposed DIVE project are collectively recognised as major focus areas for understanding crustal processes, with implications for societal challenges such as natural hazards, energy and mineral resources, deep fluids, biosphere, and ecosystem evolution. With monitoring of the seismic activity during drilling, potentially enhanced by natural fluid circulation in the underground, the community will gain new experience from a context that is different from classical geothermal investigations such as those currently carried out in sedimentary basins. Drilling operations can represent a precious source of investment in developing education platforms for schools, university students, formation of the next generation of researchers, and the larger public. The public activities could include open days at drilling sites, press releases, and presentations in schools, universities, and interested municipalities, outlining the results of both the drilling and the subsequent work related to the core samples, as well as "Ask me anything!" or "Scientist is in"type events. The proposed drilling sites will have a great impact on the general public, as well as the local population since all the drilling sites are within the Sesia-Val Grande geopark, which also includes the UNESCO World Heritage site of the Sesia Magmatic System, and the National Park of Val Grande. Therefore, the new data and consequent models obtained during the DIVE project will make the IVZ an even more attractive geopark for Earth sciences education and might provide unprecedented new insights into geothermal energy resources. A website will also be constructed to highlight any news of the ICDP-sponsored drilling operations "on air".

\section{Concluding remarks}

Numerous issues were discussed in detail during the workshop that cannot be covered in this brief report. However, all relevant information discussed during the workshop will be used to compile the full proposal. Practical but crucial issues on sampling and coring will be elaborated during the preparation of the full drilling proposal. All discipline groups will use standardised analytical methods and will also work on a generally applicable system for data management and evaluation. More information on DIVE and its progress can be found on the ICDP DIVE project's website (http://www.icdp-online.org/projects/world/europe/Ivrea/).

\section{Participants of the ICDP workshop in Baveno, Italy}

Bjarne Almqvist, Mohsen Bazargan, George Bergantz, Théo Berthet, Peter Brack, Shuyun Cao, Tobias Diehl, Rita Economos, Donato Giovannelli, Bradley Hacker, Ulrich Harms, Jörg Hermann, Klaus Holliger, Priyank Jaiswal, Ozge Karakas, Peter Kelemen, Rolf Kipfer, Antonio Langone, Julien Leuthold, Adele Manzella, Maurizio Mazzucchelli, Michael Z. McIntire, Walter Mooney, Peter Nabelek, Benoît Petri, Simona Pierdominici, Claudia Piromallo, Silvia Pondrelli, Jan-Erik Rosberg, Matteo Scarponi, Craig 
Schiffries, Anja Schleicher, Silvano Sinigoi, Thomas W. Sisson, Andrew Smye, Julien-Christopher Storck, Lorenzo Tavazzani, Riccardo Tribuzio, Lucy Tweed, Peter Ulmer, Michael Weber, and Alba Zappone.

Data availability. No data sets were used in this article.

Author contributions. OM, LZ, AZ, and MP organised and led the ICDP workshop in Baveno, Italy. GH led the working group discussions amongst the geophysicists of the ICDP workshop and initiated the 10-station broadband seismological array, which has been in operation since June 2017. MP took the lead in writing the initial draft of the manuscript. All authors contributed improvements to the final paper.

Competing interests. The authors declare that they have no conflict of interest.

Acknowledgements. ICDP is gratefully acknowledged for providing funding for the workshop in Baveno. We thank all the participants of the Ivrea ICDP workshop for their constructive input and enthusiasm, and especially Ulrich Harms for unconditional support. We are grateful to Edi Kissling for previous discussions on the geophysical Ivrea body. We acknowledge the insightful comments on the report by two anonymous reviewers. The organisers of the workshop are grateful to the late Luigi Burlini, who had already launched the idea of drilling the IVZ in 2009. MP and LZ acknowledge the support of the Swiss National Science Foundation Ambizione Fellowship and Alexander von Humboldt Postdoctoral Fellowship, respectively. Those interested in joining the DIVE project are invited to contact the authors of this article.

Edited by: Ulrich Harms

Reviewed by: two anonymous referees

\section{References}

Annen, C. and Sparks, R. S. J.: Effects of repetitive emplacement of basaltic intrusions on thermal evolution and melt generation in the crust, Earth Planet. Sci. Lett., 203, 937-955, 2002.

Berckhemer, H.: Topographie des "Ivrea-Körpers" abgeleitet aus seismischen und gravimetrischen Daten, Schweiz. Min. Petr. Mitt., 48, 235-246, 1968.

Boriani, A., Origoni Giobbi, E., Borghi, A., and Caironi, V.: The evolution of the 'Serie dei Laghi' (Strona-Ceneri and Schisti dei Laghi): The upper component of the Ivrea-Verbano crustal section; southern Alps, north Italy and Ticino, Switzerland, Tectonophys, 182, 103-118, 1990.

Brack, P., Ulmer, P., and Schmid, S.: A crustal magmatic system from the Earth mantle to the Permian surface: Field trip to the area of lower Valsesia and val d'Ossola (massiccio dei Laghi, Southern Alps, Northern Italy), Swiss Bull. Angew. Geol., 15, 3-21, 2010.
Christensen, N. I. and Mooney, W. D.: Seismic velocity structure and composition of the continental crust: A global view, J. Geophys. Res., 100, 9761-9788, 1995.

Diehl, T., Husen, S., Kissling, E., and Deichmann, N.: Highresolution 3-D P-wave model of the Alpine crust, Geophys. J. Internat., 179, 1133-1147, 2009.

Fountain, D. M.: The Ivrea-Verbano and Strona-Ceneri zones, northern Italy: a cross section of the continental crust: new evidence from seismic velocities, Tectonophys, 33, 145-166, 1976.

Hetényi, G. and AlpArray Working Group: AlpArray: an initiative for broad co-operation in broadband seismology, EPOS Newsletter, 01/2012, 2, 2012a.

Hetényi, G. and AlpArray Working Group: AlpArray - an initiative to advance understanding of Alpine geodynamics, Geophys. Res. Abstr., 14, A-10058, 2012b.

James, T.: A study of the geological structure of the Massiccio dei Laghi (Northern Italy), Unpublished PhD thesis, University of Manchester, 2001.

Khazanehdari, J., Rutter, E. H., and Brodie, K. H.: High pressure/temperature seismic velocity structure of the mid- and lower-crustal rocks of the Ivrea-Verbano zone and Serie dei Laghi, NW Italy, J. Geophys. Res., 105, 13843-13858, 2000.

Kissling, E.: Three-dimensional gravity model of the northern Ivrea-Verbano zone, in: Geomagnetic and gravimetric studies of the Ivrea zone, edited by: Wagner, J. J. and Mueller, S., 53-61, Swiss Comm. Geophysics, Attinger SA, Neuchâtel, 1984.

Klötzli, U. S., Sinigoi, S., Quick, J. E., Demarchi, G., Tassinari, C. C. G., Sato, K., and Günes, Z.: Duration of igneous activity in the Sesia Magmatic System and implications for high-temperature metamorphism in the Ivrea-Verbano deep crust, Lithos, 206-207, 19-33, 2014.

Lanza, R.: Models for interpretation of the magnetic anomaly of the Ivrea body, Geologie Alpine, 58, 85-94, 1982.

Lorenz, H., Rosberg, J.-E., Juhlin, C., Bjelm, L., Almqvist, B. S. G., Berthet, T., Conze, R., Gee, D. G., Klonowska, I., Pascal, C., Pedersen, K., Roberts, N. M. W., and Tsang, C.-F.: COSC1 - drilling of a subduction-related allochthon in the Palaeozoic Caledonide orogen of Scandinavia, Sci. Dril., 19, 1-11, https://doi.org/10.5194/sd-19-1-2015, 2015.

Molinari, I., Clinton, J., Kissling, E., Hetényi, G., Giardini, D., Stipcevic, J., Dasovic, I., Herak, M., Šipka, V., Wéber, Z., Gráczer, Z., Solarino, S., the Swiss-AlpArray Field Team, and the AlpArray Working Group: Swiss-AlpArray temporary broadband seismic stations deployment and noise characterization, Adv. Geosci., 43, 15-29, https://doi.org/10.5194/adgeo-43-152016, 2016.

Morrison, S., Pistone, M., and Kohl, L.: Studying Yellowstone by integrating deep carbon science, EOS, 98, https://doi.org/10.1029/2017EO076209, 2017.

Quick, J. E., Sinigoi, S., and Mayer, A.: Emplacement dynamics of a large mafic intrusion in the lower crust, Ivrea-Verbano Zone, northern Italy, J. Geophys. Res., 99, 21559-21573, 1994.

Quick, J. E., Sinigoi, S., Snoke, A. W., Kalakay, T. J., Mayer, A., and Peressini, G.: Geologic map of the Southern Ivrea-Verbano Zone, Northwestern Italy, U.S. Geological Survey, Reston, Virgina, VA, 2003.

Rutter, E., Brodie, K., and Evans, P.: Structural geometry, lower crustal magmatic underplating and lithospheric stretching in the Ivrea-Verbano Zone, N. Italy, J. Struct. Geol., 15, 647-552, 1993. 
Rutter, E., Brodie, K., James, T., Blundell, D. J., and Waltham, D. A.: Seismic Modeling of Lower and Mid-Crustal Structure as Exemplified by the Massiccio dei Laghi (Ivrea-Verbano Zone and Serie dei Laghi) Crustal Section, Northwestern Italy, in: Heterogeneity in the Crust and Upper Mantle, edited by: Goff, J. A. and Holliger, K., Kluwer Academic/Plenum Publishers, 67-97, 2003.

Salisbury, M. H. and Fountain, D. M.: Exposed Cross-Sections of the Continental Crust, NATO ASI Series, Series C: Mathematical and Physical Sciences 317, Kluwer Academic Publisher, Dordrecht, Netherlands, 658 pp., 1990.

Scarponi, M., Hetényi, G., Plomerová, J., Solarino, S., Berthet, T., Baron, L., AlpArray-lvrea Working Group, and AlpArray Ivrea Field Team: High-resolution imaging of the Ivrea Geophysical Body: A receiver function and gravity approach, 15th Swiss Geoscience Meeting, 17-18 November 2017, Davos, Switzerland, 2017.

Schmid, S. M., Kissling, E., Diehl, T., van Hinsbergen, D. J. J., and Molli, G.: Ivrea mantle wedge, arc of the Western Alps, and kinematic evolution of the Alps-Appenines orogenic system, Swiss J. Geosci., https://doi.org/10.1007/s00015-016-0237-0, 2017.

Sinigoi, S., Quick, J. E., Demarchi, G., and Klotzli, U. S.: The role of crustal fertility in the generation of large silicic magmatic systems triggered by intrusion of mantle magma in the deep crust, Contrib. Mineral. Petrol., 162, 691-707, 2011.
Sleep, N. H.: Formation of oceanic crust: Some thermal constraints, J. Geophys. Res., 80, 4037-4042, 1975.

Solano, J. M. S., Jackson, M. D., Sparks, R. J. S., and Blundy, J. D.: Evolution of major and trace element compositions during melt migration through crystalline mush: Implications for chemical differentiation in the crust, Am. J. Sci., 314, 895-939, 2014.

Spada, M., Bianchi, I., Kissling, E., Piana Agostinetti, N., and Wiemer, S.: Combining controlled-source seismology and receiver function information to derive 3-D Moho topography for Italy, Geophys. J. Internat., 194, 1050-1068, 2013.

Wagner, J. J., Klingelé, E., and Mage, R.: Regional geomagnetic study of the southern border of the Western Alps, The Ivrea body, in: Geomagnetic and Gravimetric studies of the Ivrea Zone, edited by: Wagner, J. J. and Müller, S., Beitr. Geol. Schweiz Geophys, 21, Kümmerly \& Frey, Bern, 21-31, 1984.

Wagner, M., Kissling, E., and Husen, S.: Combining controlledsource seismology and local earthquake tomography to derive a 3-D crustal model of the western Alpine region, Geophys. J. Internat., 191, 789-802, 2012.

Weiss, T., Siegesmund, S., Rabbel, W., Bohlen, T., and Pohl, M.: Physical properties of the Lower continental crust: an anisotropic perspective, Pure Appl. Geophys., 156, 97-122, 1999. 